\title{
Decision Support Approach for Managers in the Application of the CSR Concept
}

\author{
Nora Rodek Berkes \\ University of Pannonia, Hungary
}

\begin{abstract}
In today's globalized world we hear more and more about sustainable development, ethical corporate governance, ecological footprint and similar concepts that are inspiring us to behave and operate responsibly from individuals to large enterprises. Previous researches on the subject have highlighted the fact that most of the company executives are not aware of the elements of the CSR concept (Corporate Social Responsibility) and they identify CSR as environmental protection and charity. A directive of CSR is needed which enables companies to learn about the concept of CSR and its elements, so this information could help them in responsible decision making. During the research the CSR excellence management and assessment tool (CSR EMAT) was developed based on the logic of the EFQM Excellence Model. It serves as a guideline and evaluation system for companies and makes them comparable as a result of the evaluation process. Companies can be divided into different groups according to their CSR excellence as it is supported by the examples in the study.
\end{abstract}

Keywords: Corporate Social Responsibility, sustainability, management, EFQM Excellence Model, CSR EMAT, CSR excellence management and assessment tool JEL classification: M14

\section{Introduction}

According to previous research in Hungary, the scope of the concept of CSR is not clear among the managers and they are not familiar with its contents neither. Most of the company leaders identify CSR with environmental protection, charity and sponsorship. The CSR concept has although much more elements. We cannot expect from managers to be able to decide responsibly without knowing this information. The research aimed to develop a quality management system and guidance to help managers understand the CSR approach and its introduction into the corporate practice. Following the literary background of the CSR approach and sustainability, the CSR excellence model and the assessment criteria will be presented with the results obtained during the evaluation.

Sustainable development must be based on ecological principles, the honor and morality between generations and the various social interest groups. In order to achieve sustainability it is not enough to operate profitably while reducing environmental impacts, much more is needed: commitment, long-term and responsible thinking which monitors the effects on society as well. Corporate social responsibility is an important means of achieving sustainability. Sustainable development meets the needs of the present, without compromising the needs of the future generations (Brundtland, 1987). Although the conscious and environmentally decisions promoting sustainability refers to the future, they need to be taken into consideration in the present. Since changing the opinions and attitudes is a slow process, it is expedient in case of present decisions to take into 
account the circumstances with the support of appropriate management techniques in order to enhancing effectiveness.

Responsible management assumes responsibility for the triple bottom line (sustainability), stakeholder value (responsibility), and moral dilemmas (ethics). Responsible managers should think of social efficiency as an evaluation criterion of their own management processes. How much social welfare is created? Are the employees satisfied with the working conditions? Are they motivated well? Are they growing as human beings in their work, or are they exploited so that they represent lost social capital? Performance for a responsible manager is defined as a combination of social, environmental, and economic performances. In 2009, senior management thinker Gary Hamel brought together a group of thirty-five eminent management specialists called 'the renegades' who developed twenty-five recommendations for management of the future. Their first three recommendations were all related to ethics, sustainability and responsibility. 1. Management must orient itself to achieve noble, socially significant goals. 2. They must embed the ideas of community and citizenship in management systems. There is a need for processes and practices that reflect the interdependence of all stakeholder groups. 3 . Reconstruct management's philosophical foundations (Laash, 2015).

If we take the definition of sustainability into consideration, we can see that the two concepts are related and complementary. CSR means the activities of a company that support the society while relating to legal standards and the direct interests of the company. Sustainable development meets the needs and expectations of humanity without threatening the future generation. The responsible operation has a number of results that supports sustainability and thereby the long-term competitiveness as well (Szlávik, 2013).

Table 1

The Results of the Responsible Operation

The results of the responsible operation

- the company profit will grow, it will be easier to get corporate resources as the company will be more attractive to investors

- it improves the company's reputation and image

- the loyalty and motivation will rise among the stakeholders, especially the consumers and staffwhich reduces the internal monitoring and coordination costs

- improves the competitive position of the company, increases the market share - niche markets can be also reached

- cost savings can be achieved (environmental investments), the company will be attacked less by the NGOs, the media and other stakeholders- risk management

- reduces the risk of tightening legislation

- transaction costs will be reduced because of the relationship and trust

- as the governments and international organizations consider CSR as a more important question, the company can get subsidy easier through its responsible behavior

- CSR can be the tool of stakeholder relationship management

- it develops proactivity

- it provides opportunities for innovation (e.g. SRI - responsible investment products, or environmentally friendly products)

Source: authors research data (2015)

Table 1 summarizes the results of the responsible operation. The application of the concept of CSR can result a number of positive effects for companies. It can be clearly seen that without the commitment of leaders social responsibility cannot work.

The implementation of the corporate social responsibility concept is affected by the people who make up the organization. The key element of CSR-oriented 
management is the leadership itself and its commitment, habit, ethical compliance, disposition and socialization experience. The social commitment of the company to the practical aspects of CSR: 1. unifying the CSR orientation of the management 2. the development and operation of reporting and measurement systems 3 . the continuous improvement of the quality of work 4 social and eco-labels, the purposeful and conscious use of product marks 5 implementing socially responsible investments. (Kun, 2004)

\section{Theoretical background}

According to World Business Council for Sustainable Development, the definition of CSR is the following: commitment of business to contribute to sustainable economic development, with the employees, their families, local community and society cooperating in order to improve the quality of life. (EC, 2001) CSR is regarded as a set of tools that improves working conditions beyond legal requirements and it is favorable for the society. (Vogel, 2006) Many companies are focusing on corporate social responsibility issues but unfortunately, most companies are still based on selfinterest and make CSR the part of their economic calculation, which is the opposite of altruistic ethical behavior. (Holliday, 2002) The main points of Corporate Social Responsibility (CSR) concepts are; that after mapping who their stakeholders are, the company has to incorporate these CSR values and interests into their business operation while maintaining their profitability. Socially responsible behavior radiates confidence towards both employees and consumers. (Frank, 2004) Many companies, however, see that a few donations and environmental measures are enough for responsible behavior. However, for the sustainable development a longterm strategy is needed.

Corporate Social Responsibility concentrates not only on environmental issues but also on communication and employee care, so applying this concept can be a great tool in order to build trust, raise employee satisfaction and motivation. The essence of CSR activity is communication, including internal and external relationship with stakeholders. The stakeholders' views and ideas are becoming increasingly important so the bidirectional communication is essential. There are many positive effects of CSR that can be observed in case of companies.

Table 2

CSR Guidelines and Standards

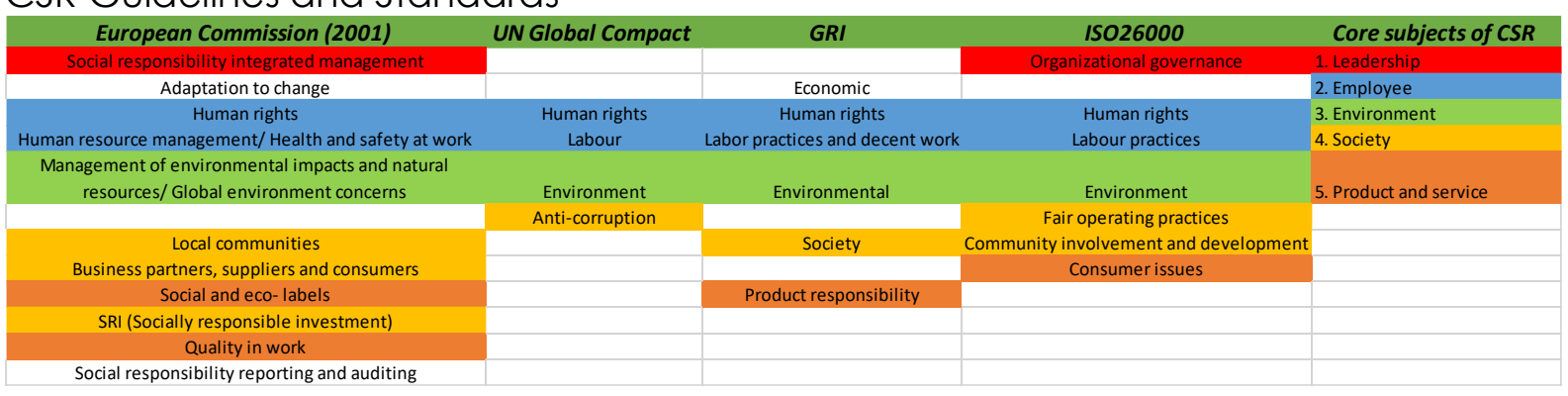

Source: authors research data (2016)

Table 2 demonstrates the international CSR guidelines and standards and their core subjects. Since the early 1990s, the European Commission has taken an active interest in corporate social responsibility (CSR). In 2001, this interest manifested itself in the form of a green paper (or consultation document) entitled 'Promoting a European framework for corporate social responsibility'. This 35-page document sets 
out the principles underlying CSR and introduces some of the sustainability tools at the disposal of companies and governments. The UN Global Compact is a call to companies everywhere to: 1. voluntarily align their operations and strategies with ten universally accepted principles in the areas of human rights, labor, environment and anti-corruption and 2 take actions in support of UN goals, including the Millennium Development Goals. The Global Reporting Initiative (GRI) is a leading organization in the sustainability field. GRI promotes the use of sustainability reporting as a way for organizations to become more sustainable and contribute to sustainable development. GRI has pioneered and developed a comprehensive Sustainability Reporting Framework that is widely used around the world. A sustainability report is a report published by a company or organization about the economic, environmental and social impacts caused by its everyday activities. ISO 26000:2010 provides guidance rather than requirements, so it cannot be certified to unlike some other well-known ISO standards. Instead, it helps clarify what social responsibility is, helps businesses and organizations translate principles into effective actions and shares best practices relating to social responsibility globally. It is aimed at all types of organizations regardless of their activity, size or location. The standard was launched in 2010 following five years of negotiations between many different stakeholders across the world. Representatives from government, NGOs, industry, consumer groups and labor organizations around the world were involved in its development.

CSR has no internationally agreed definition and there is no precise determination of its areas. I collected the guidelines and standards related to CSR into a table to see what are the core subjects they have in common. As a result, the determined elements of the CSR concept can be found in the last column of the table.

\section{Methodology}

My research was motivated by the idea to develop a guidance of CSR which enables companies to learn about the concept and its elements, so this information could help them in responsible decision making. After collecting the elements of international standards and directives for social responsibility and sustainability, I was looking for a quality management system which framework is appropriate to develop the CSR excellence model. The CSR excellence management and assessment tool (CSR EMAT) was developed based on the logic of the EFQM Excellence Model.

The EFQM Excellence Model is based on a set of European values and was introduced in 1992. Today, it is the most widely used business excellence model in Europe, more than 30,000 organizations use it to improve performance. The model is a practical, non-prescriptive framework that enables organizations to assess where they are on the path to excellence and provide a basic structure for the organization's management system. The EFQM Excellence model contains three integrated components: the fundamental concepts of excellence, the EFQM excellence model and the RADAR logic. The fundamental concepts of excellence are the underlying principles which are the essential foundation of achieving sustainable excellence for any organization. The EFQM Excellence Model is a framework to help organizations convert the fundamental concepts and RADAR logic into practice. Radar logic is a dynamic assessment framework and management tool that provides a structured approach to question the performance of an organization. It also supports the scoring mechanism behind the assessment schemes and can help to lead change and manage improvement projects in an organization. 
The EFQM Excellence Model is a framework based on nine criteria. Five of these are 'Enablers' and four are 'Results'. The 'Enabler' criteria cover what an organization does and how it does it. The 'Results' criteria cover what an organization achieves. 'Results' are caused by 'Enablers' and 'Enablers' are improved using feedback from 'Results'. Each criterion is supported by a number of criterion parts. Criterion parts are statements that describe in further examples what should be considered in the course of an assessment.

\section{Results}

Table 3

CSR Excellence Model

\begin{tabular}{|c|c|c|c|c|}
\hline \multicolumn{3}{|l|}{ Enablers } & \multicolumn{2}{|l|}{ Results } \\
\hline \multirow[t]{3}{*}{$\begin{array}{l}\text { 1.Responsible } \\
\text { leadership }\end{array}$} & 2.Employee & \multirow[t]{3}{*}{$\begin{array}{l}\text { 5.Products } \\
\text { \& Services }\end{array}$} & 6.Employee results & \multirow[t]{3}{*}{$\begin{array}{l}\text { 9.CSR } \\
\text { Results }\end{array}$} \\
\hline & 3.Strategy & & 7.Customer results & \\
\hline & 4.Society\&Environment & & $\begin{array}{l}\text { 8.Society\&Environment } \\
\text { results }\end{array}$ & \\
\hline
\end{tabular}

Learning, Creativity and Innovation

Source: Author's illustration

The areas of the CSR Excellence Model were determined on the basis of the international standards and guidelines. The certain areas of the model are also divided into criterion parts on the basis of the sub-areas of international standards and guidelines and the collected content elements of 250 European CSR reports. The assessment tool is intended to evaluate the CSR activities of organizations of all sizes and from all sectors in order to be able to compare them. It was therefore important to collect all the elements of CSR from the reports and standards that are used in practice. Beyond the assessment, the aim of the CSR EMAT system is to provide guidance for company managers in the interpretation of the CSR approach and a kind of best practice data base that can help them to learn about the opportunities of applying this concept. The fundamental concepts of the CSR Excellence Management and Assessment Tool (CSR EMAT) are:

- Responsible and ethical management,

- Strategy for responsible and sustainable operation and development,

- Creating value for the society,

- Taking into account the interests of stakeholders,

- Employee appreciation and motivation,

- Relations with partners and customers,

- Responsible product and service,

- Being responsibility for the environment.

The CSR EMAT is a complex management guidance that beside the fundamental concepts and their definitions also contains the assessment tool that can evaluate the intensity of the CSR activity of a certain company. 


\section{Table 4}

The Results of the Company's CSR Excellence

\begin{tabular}{|c|c|c|c|c|c|c|}
\hline \multicolumn{7}{|c|}{ The result of the company's CSR excellence } \\
\hline Record the number of ticks scored & $\mathrm{E}$ & $\mathrm{D}$ & $\mathrm{C}$ & $\mathrm{B}$ & $\mathrm{A}$ & \% Achievement \\
\hline 1. Responsible leadership & 0 & 0 & 1 & 2 & 2 & \\
\hline 2. Employee & 0 & 0 & 0 & 0 & 6 & 100 \\
\hline 3. Strategy & 0 & 0 & 0 & 2 & 2 & 87,5 \\
\hline 4. Society\&Environment & 0 & 0 & 1 & 2 & 2 & 80 \\
\hline 5. Products\&Services & 0 & 0 & 0 & 0 & 5 & 100 \\
\hline 6. Employee results & 0 & 0 & 1 & 1 & 5 & 89,3 \\
\hline 7. Customer results & 1 & 0 & 0 & 1 & 3 & 75 \\
\hline 8. Society\&Environment results & 0 & 1 & 0 & 0 & 4 & 85 \\
\hline 9. CSR results & 1 & 0 & 1 & 2 & 1 & 60 \\
\hline Total number of ticks (a) & 2 & 1 & 4 & 10 & 30 & 47 \\
\hline Factor (b) & 0 & 25 & 50 & 75 & 100 & \\
\hline Value (a x b) & 0 & 25 & 200 & 750 & 3000 & 3975 \\
\hline Total/47=84,6\% CSR excellence & \multicolumn{7}{|l}{} \\
\hline
\end{tabular}

Source: Author's illustration

Table 4 shows the results of the company's CSR excellence at the end of the assessment tool. Each company has this table and the graphical display of its results (Figure 1) following the completion of the evaluation system. The assessment tool consists of statements concerning the 9 areas (Enablers and Results) of the CSR excellence model. Table 4 shows the CSR excellence of a financial services company employing 60,000 thousand employees. $84,6 \%$ is an outstanding result. This company is a pioneer at this field in Hungary and sets an example for the other companies in CSR activity.

Figure 1

The graphical display of the CSR excellence

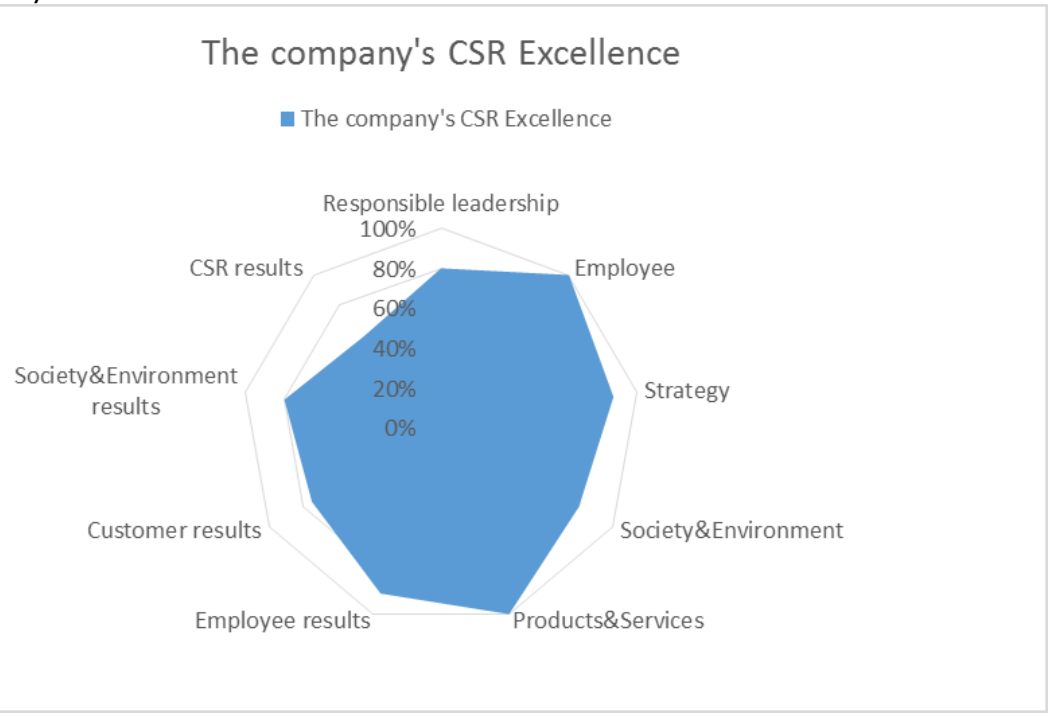

Source: Author's illustration

The validation of the evaluation system is in progress. I have evaluated 16 companies so far from small, medium to large companies from all sectors. The results of the evaluated companies have been summarized in Table 5. The results are very convincing; therefore I can state that with the application of the evaluation system the intensity of CSR in companies can be measurable and comparable. 
Table 5

The results of the evaluated companies with CSR EMAT

\begin{tabular}{cccc}
\hline Number of employees & Company Profile & Ownership structure & CSR Excellence \\
\hline 60000 & financial services & foreign ownership & $84,6 \%$ \\
952 & tire production & foreign ownership (French) & $61,7 \%$ \\
8000 & financial services & joint ownership & $61,70 \%$ \\
15 & wholesale sales & foreign ownership & $79,8 \%$ \\
330 & industrial cutting & joint ownership & $43,62 \%$ \\
130 & Industrial Fixtures & foreign ownership & $45,75 \%$ \\
75 & timber industry & foreign ownership & $71,8 \%$ \\
53 & wholesale clothing & Hungarian-owned & $47,34 \%$ \\
2000 & food trade & foreign ownership & $74,4 \%$ \\
29 & printing industry & Hungarian-owned & $57,45 \%$ \\
4600 & public administration & Hungarian-owned & $54 \%$ \\
110000 & electronic products & foreign ownership & $66 \%$ \\
111 & pharmaceutical industry & foreign ownership (French) & $57,98 \%$ \\
776 & electronic products & foreign ownership & $41,3 \%$ \\
2700 & industrial parts & Hungarian-owned & $71,81 \%$ \\
& manufacturing & & $76,59 \%$ \\
\hline 1600 & telecommunications & foreign ownership (English) & \\
\hline
\end{tabular}

Source: Author's illustration

The results show a very mixed picture as in the sample there are small, medium and large companies as well. In Table 5 I collected different data about the evaluated companies to show that there might be correlation between the CSR intensity and the profile, the number of employees and the ownership structure of the company. The validation confirmed the applicability of the evaluation system, but the number of the sample is very small therefore I cannot draw definitive conclusions.

\section{Discussion and Conclusion}

The hypothesis of this research was that the EFQM excellence model is an appropriate framework for developing a CSR Excellence model. This hypothesis has been successfully confirmed. Previous research in Hungary revealed that the company managers are not familiar with the concept of CSR. In many cases, they operate in a socially responsible way without knowing anything about CSR. The CSR EMAT can help them to identify the CSR activities of their companies and it also shows improvement opportunities, as the model is based on the logic of TQM (Total Quality Management). With the use of the assessment tool the CSR intensity of different companies (in size, profile and ownership structure) can be comparable that also gives further research opportunities. I would like to continue this research to obtain a representative sample among small, medium and large companies operating in Hungary. I plan to collect all the results in an online database for further analysis. It would be worth to evaluate different companies in other countries as well and to compare the results to see whether there is a correlation between CSR intensity and national culture.

\section{References}

1. Benn, S., Bolton, D. (2011): Key Concepts in Corporate Social Responsibility. SAGE Publications, London.

2. Brundtland, H. (1987): Report of the World Commission on Environment and Development: Our Common Future. Oslo. (http://www.un-documents.net/ourcommon-future.pdf) 
3. European Comission (2005): Opinion of the European Economic and Social Committee on Information and measurement instruments for corporate social responsibility (CSR) in a globalised economy.

4. EuropoeanComission (2002): Communication from the Commission concerning Corporate Social Responsibility: A business contribution to Sustainable Development.

5. Fekete, L. (2005): Hungary - Social Welfare Lagging Behind Economic Growth, in Habish, A. - Jonker, J. - Wegner, M. - Schmidpeter, R. (Eds): Corporate Social Responsibility Across Europe, Springer, Berlin-Heidelberg.

6. Frank, R. H. (2004): What Price the Moral High Ground? Ethical Dilemmas in Competitive Environments, Princeton University Press, Princeton.

7. Global Compact Foundation. Main page. Available at: http://globalcompactfoundation.org/ (5/5/2016)

8. Global Reporting. Main page. Available at: www.globalreporting.org (5/5/2016)

9. Hatch, NW - JH Dyer (2004): Human capital and learning as a source of sustainable competitive advantage. Strategic Management. Journal, 25: 1155-1 178

10. Holliday, C. O. - Schmidheiny, S. - Watts, P. (2002): Walking the Talk - The Business Case for Sustainable Development. Greenleaf Publishing, Berrett-Koehler Publishers, Inc. San Francisco.

11. Idowu, S. O. (2013): Encyclopedia of Corporate Social Responsibility. Springer, New York ISBN 978-3-642-28035-1

12. Idowu, S. O., Filho W. L., (2009): Professionals' Perspectives of Corporate Social Responsibility. Sringer, New York ISBN 978-3-642-02629-4

13. International Federation for Human Rights (2006): An Overview of Corporate Social Responsibility in Hungary, FIDH, Budapest.

14. International Institute for Sustainable Development. Main page. Available at: www.iisd.org (5/5/2016)

15. ISO. Main page. Available at: http://www.iso.org/ (5/5/2016)

16. Kun, A. (2004): The basic lines of the thematization of Corporate social commitment in the European Union.

vállalatiszociáliselkötelezettségtematizálásánakalapvonalaiazEurópaiUnióban.)

Jogelméletiszemle (http://www.jogiforum.hu/folyoiratok/11/68)

17. Laasch, O., Conaway R. N. (2015): Principal of Responsible Management-Glocal Sustainability, Responsibility and Ethics. Cengage Learning, Stamford, USA ISBN 978-1285-08026-0

18. Segal, J-P. - Sobczak, A. - Triomphet C-A. (2003): Corporate social responsibility and working condition. European Foundation for the Improvement of Living and Working Conditions, Dublin.

19. Szlávik, J. (2009): Corporate Social Responsibility. (In Hungarian: A vállalatoktársadalmifelelősségvállalása.) Complex KiadóKft., Budapest.

20. Templar, R. (2005): The rules of management the definitive guide to managerial success. Pearson Education Limited.

21. The EFQM Excellence Model. Main page. Available at: http://www.efam.org/ $(5 / 5 / 2016)$

22. United Nations Development Program. Available at: http://www.undp.org/content/undp/en/home/mdgoverview/post-2015development-agenda.html (5/5/2016)

23. Vogel, D. (2006): The Market for Virtue - The Potential and Limits of Corporate Social Responsibility. Brookings Institution Press, Washington, D. C.

\section{About the author}

Nora Rodek Berkes is a lecturer at University of Pannonia Nagykanizsa Campus. She is a Ph.D. student in Management and Business Administration at the Doctoral School of University of Pannonia. Her research topics are CSR (Corporate Social Responsibility), sustainable and responsible management, social innovation. The author can be contacted at rodek.nora@gmail.com. 